\title{
Lung abscess in a young patient
}

\section{Ana Margarida Fernandes, Diana Gomes Pedreira, Sérgio Janeiro, Manuela Fera}

Department of Internal Medicine, Hospital S Bernardo, Centro Hospitalar de Setúbal, EPE, Portugal

\section{Correspondence to} Dr Ana Margarida Fernande, amargaridagf@gmail.com

\section{DESCRIPTION}

A 21-year-old man with no clinically relevant medical history presented to the emergency room with a 3 -week history of cough and fever. He had already been evaluated by his family practice physician who prescribed a 3-day course of azithromycin. The patient reported mild improvement of symptoms that lasted about 2 weeks. Four days before the admission he again reported to his doctor with recrudescence of symptoms. He was prescribed a new course of antibiotics with a different macrolide (clarithromycin). The patient's cough showed no improvement and he again reported with fever (maximal temperature $39^{\circ} \mathrm{C}$ ) that did not improve with antipyretics.

At admission, observation showed fever (tympanic temperature of $38.6^{\circ} \mathrm{C}$ ) with chills. He had intense cough without sputum and showed no signs of respiratory distress. Pulmonary auscultation revealed rude murmur on both hemithoraces. The laboratory results revealed an elevated C reactive protein of $11.78 \mathrm{mg} / \mathrm{dL}$ and leukocytosis of $14800 / \mu \mathrm{L}$. A posteroanterior chest X-ray showed a round-shaped cavity containing an airfluid level, with adjacent consolidation (figure 1). A CT scan of the chest confirmed the presence of consolidation in the inferior left lobe consistent with pneumonia that had complicated with lung abscess (figure 2).

Given that lung abscess are usually due to aspiration, ${ }^{1}$ the patient was asked about episodes of loss of consciousness, like seizures or alcohol abuse, which he denied. His HIV test was negative and no history of tuberculosis contact was determined.

Blood cultures drawn at admission were sterile probably due to prior antibiotic therapy. ${ }^{2} \mathrm{He}$ was given an 8-day course of piperacillin/tazobactam

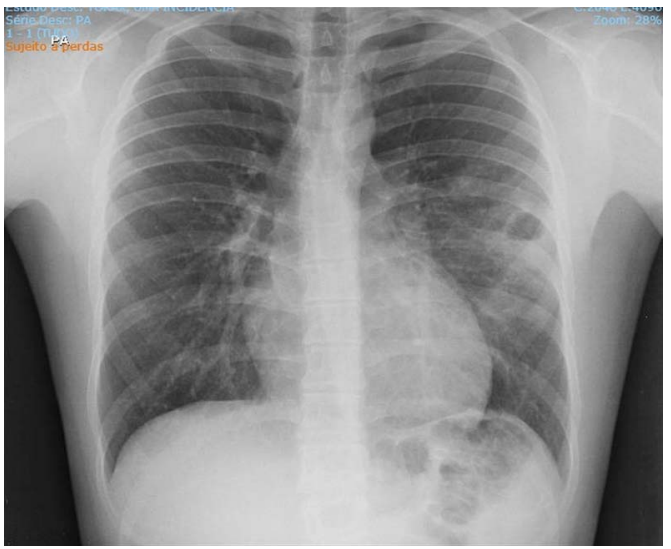

Figure 1 Chest X-ray showing a cavity containing an air-fluid level with adjacent consolidation appearance.

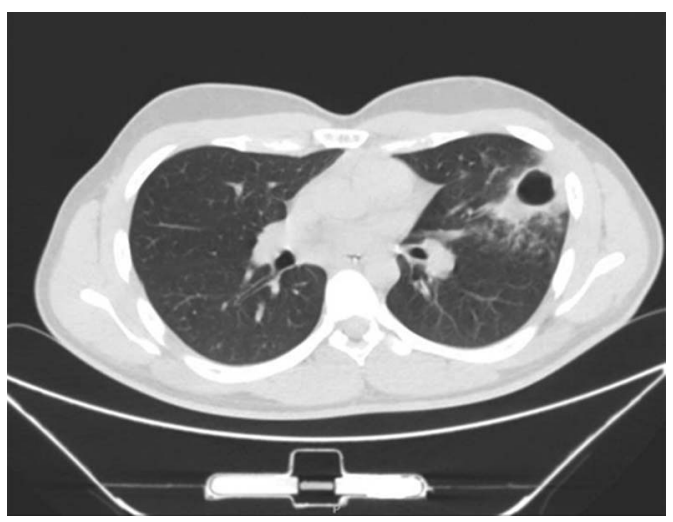

Figure 2 CT scan showing consolidation of inferior left lobe consistent with pneumonia with evolution to lung abscess.

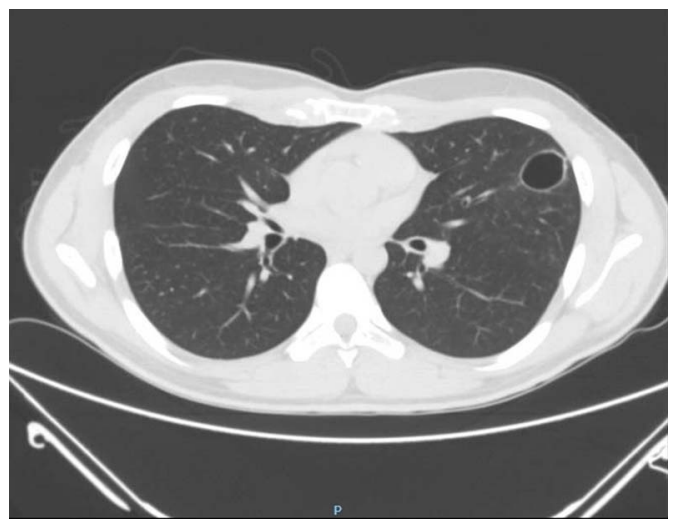

Figure 3 CT scan after resolution of consolidation with persistence of the cavity.

with improvement of symptoms. Laboratory evaluation showed reduction of acute phase markers.

Follow-up of the CT scan of the chest revealed resolution of consolidation with persistence of the cavity (figure 3 ).

\section{Learning points}

- Pulmonary abscess is not a frequent pathology in internal medicine ward, its clinical manifestations are non-specific and it affects mainlymen. ${ }^{1}$

- A positive blood or pleural culture is seen in less than $20 \%$ of patients with pneumonia. ${ }^{2}$

- The CT scan indisputably plays a key role in pulmonary infections given that standard radiography alone is lacking in specificity. ${ }^{3}$ 
Acknowledgements The authors would like to thank Dr António Meleiro e Dra Paula Lopes.

\section{Competing interests None.}

Patient consent Obtained.

Provenance and peer review Not commissioned; externally peer reviewed.

\section{REFERENCES}

1 Monteiro R, Alfaro TM, Correia L, et al. [Lung abscess and thoracic empyema: retrospective analysis in an internal medicine department]. Acta Med Port 2011;24 (Suppl 2):229-40.

2 Nair GB, Niederman MS. Community-acquired pneumonia: an unfinished battle. Med Clin North Am 2011;95:1143-61.

3 Beigelman-Aubry C, Godet C, Caumes E. Lung infections: the radiologist's perspective. Diagn Interv Imaging 2012;93:431-40.

Copyright 2014 BMJ Publishing Group. All rights reserved. For permission to reuse any of this content visit http://group.bmj.com/group/rights-licensing/permissions.

BMJ Case Report Fellows may re-use this article for personal use and teaching without any further permission.

Become a Fellow of BMJ Case Reports today and you can:

- Submit as many cases as you like

- Enjoy fast sympathetic peer review and rapid publication of accepted articles

- Access all the published articles

- Re-use any of the published material for personal use and teaching without further permission

For information on Institutional Fellowships contact consortiasales@bmjgroup.com

Visit casereports.bmj.com for more articles like this and to become a Fellow 